\title{
Heavy Metals Accumulation and Health Risk Consumption in Some Vegetables, Isfahan, Iran
}

\author{
Arasb Dabbagh Moghadam ${ }^{1,{ }^{*}}$ and Ahmad Shahmoradi ${ }^{2}$ \\ ${ }^{1}$ Aja University of Medical Sciences, Tehran, Iran \\ ${ }^{2}$ Isfahan University of Technology, Isfahan, Iran \\ Corresponding author: Aja University of Medical Sciences, Tehran, Iran. Email: dr.arasb@gmail.com \\ Received 2020 January 26; Revised 2020 October 03; Accepted 2020 October 25.
}

\begin{abstract}
Heavy metals (HM) can enter the human body via food chains or contaminate groundwater resources. The current study aimed to investigate HM contamination in vegetables and its associated health index risk (HIR) in Isfahan, Iran. The lowest amount of HM was

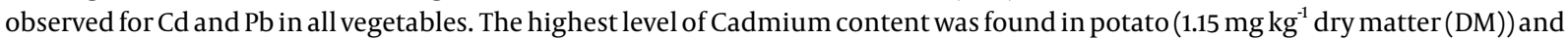
spinach (1.18 mg kg-1 DM). The highest levels of As and Cu were observed in lettuce, while the lowest content of Cu was in the carrot. Moreover, the highest content of $\mathrm{N}\left(344 \mathrm{mg} \mathrm{kg}^{-1} \mathrm{DM}\right)$ was obtained in spinach. The As and P were higher than standard amounts, and HIR was higher than 1 for these two elements. Heavy metal's HIR through ingestion vegetables were a great concern, and there has been particularly increased attention to As. A great understanding of the ecological effects of HM on soils and vegetables is needed to develop management options.
\end{abstract}

Keywords: Vegetables, Heavy Metals, Daily Intake, Health Risk Index

\section{Background}

Heavy metals (HM) pollution is one of the biggest environmental issues of our era. Both natural and anthropological sources have an important role in the expansion of HM pollutions (1). The contamination of agricultural soils and vegetables by HM is one of the most severe ecological problems all around the world (2). It can easily affect human health via entering the food chain and direct ingestion (3-5). Vegetables are an important component of the human diet, which contain carbohydrates, proteins, vitamins, minerals, and $\operatorname{HM}(6,7)$. There are different routes of HM exposure, the most important of which is the contaminated food chain, especially vegetables (8). Food safety has been the focus of several studies, which have investigated the risks associated with contamination of food resources (9). It's well documented that contamination of vegetables by HM is on the rise (10-13). However, plant species differ in their efficiency to absorb HM (14).

\section{Objectives}

The current study aimed to investigate HM levels of vegetables and health index risk (HIR) due to the consumption of vegetables in Isfahan Province, Iran.

\section{Methods}

\subsection{Plant Sampling}

Vegetable samples (potato, cucumber, tomato, carrot, lettuce, and spinach) were collected from local markets of Isfahan (Iran) in November 2018 on different days to determine nutrients (cadmium $(\mathrm{Cd})$, copper $(\mathrm{Cu})$, iron $(\mathrm{Fe})$, nickel $(\mathrm{Ni})$, manganese $(\mathrm{Mn})$, lead $(\mathrm{Pb})$, zinc $(\mathrm{Zn})$, arsenic (As), phosphorus (P), and nitrate $(\mathrm{N})$ ).

\subsection{Extraction of Plant}

Crop samples were washed three times with distilled water, then dried and milled $\left(72^{\circ} \mathrm{C}\right.$ for $\left.48 \mathrm{~h}\right)$. Afterward, 0.2 g samples were weighted and $4 \mathrm{~mL} \mathrm{HNO}_{3}$ and $0.2 \mathrm{~mL} \mathrm{H}_{2} \mathrm{O}_{2}$ (37\%) were used for digestion at $100^{\circ} \mathrm{C}$ for 90 min and finally filtered by Whatman 42 (15). HMs were determined using atomic absorption spectroscopy (Varian, 220). Phosphorus was measured by a colorimetrically method. Nitrate was measured by the Jones procedure (16).

\subsection{Daily Intake and Health Risk Index}

The daily intake of metals (DIM) was calculated using the following equation:

$$
D I M=\frac{C_{\text {element }} \times C_{\text {factor }} \times D_{\text {plant }}}{B W}
$$


Where; $\mathrm{C}_{\text {element }}$ is element content $\left(\mathrm{mg} \mathrm{kg}^{-1}\right)$ in dry matter of plant (DM); $\mathrm{C}_{\text {factor }}$ is the conversion factor from fresh to dry weight of plants which was considered as 0.085 (17, 18 ); $D_{\text {plant }}$ is DI of plants. Iranian family consumption represented by Institute of Standards and Industrial Research of Iran 2010 were $0.109 \mathrm{~kg} \mathrm{day}^{-1}$ for cucumber and tomato, $0.058 \mathrm{~kg} \mathrm{day}^{-1}$ for lettuce and spinach, $0.069 \mathrm{~kg} \mathrm{day}^{-1}$ for potato, and $0.039 \mathrm{~kg} \mathrm{day}^{-1}$ foe carrot. In addition, $70 \%$ of the mentioned intake for adults was considered for children. The BW is average body weight ( $60 \mathrm{~kg}$ for adults and 32.70 $\mathrm{kg}$ for children) $(19,20)$.

Health risk assessment for consumers, based on their intake of metal-contaminated crops, was characterized using a health risk index (HRI) as following:

$H R I=\frac{D I M}{R f D}$

Where; DIM is daily intake $\left(\mathrm{mg} \mathrm{kg} \mathrm{BW}^{-1} \mathrm{day}^{-1}\right)$; $\mathrm{RfD}$ is the reference oral doses for $\mathrm{Cd}, \mathrm{Cu}, \mathrm{Fe}, \mathrm{Mn}, \mathrm{Ni}, \mathrm{Pb}, \mathrm{Zn}, \mathrm{N}, \mathrm{P}$, and As which they are $0.0005,0.037,0.3,0.14,0.2,0.014,0.3$, $0.16,0.00002$, and $0.0003 \mathrm{mg} \mathrm{kg}^{-1} \mathrm{day}^{-1}$, respectively (21).

\subsection{Data Analysis}

The data were analyzed as a completely randomized design by the GLM (general linear models) procedure of SAS 2004. Significant differences were compared by Duncan's multiple range test $(\mathrm{P} \leq 0.05)$.

\section{Results}

\subsection{Elements Concentration in Plant Tissues}

Cadmium in potato (1.153 $\mathrm{mg} \mathrm{kg}^{-1} \mathrm{DM}$ ) and spinach $\left(1.180 \mathrm{mg} \mathrm{kg}^{-1} \mathrm{DM}\right)$ were significantly higher than other vegetables (Table 1). Among all investigated vegetables, the maximum $\mathrm{Pb}$ was observed in potato. The highest and lowest levels of Mn were found in lettuce and spinach, respectively. The highest As ( $\left.16.02 \mathrm{mg} \mathrm{kg}^{-1} \mathrm{DM}\right)$ was also observed in lettuce.

In this study, Cadmium levels were lower than reported values (12.5 mg kg ${ }^{-1}$ for vegetables (22); $25 \mathrm{mg} \mathrm{kg}^{-1}$ for vegetables in polluted soils; $0.98 \mathrm{mg} \mathrm{kg}^{-1}$ in wheat,(23)). However, lower levels of $\mathrm{Cd}$ were reported in other studies $(24,25)$. The higher levels of $\mathrm{Cd}$ and $\mathrm{Pb}$ in potatoes and vegetables can be attributed to the fertilizers and sludge application. The mobility rate of $\mathrm{Pb}$ in soil and plant was very slow, and $\mathrm{Pb}$ rarely transports from roots to shoot parts of the plant (26).

In addition, the lowest level of $\mathrm{Ni}$ was measured in carrots. Evidence regarding the toxicity of Manganese in plants are not sufficient (27). The high concentration of Zn in cucumber and tomato might indicate the accumulation of $\mathrm{Zn}$ in soil. The abuse of pesticides and industrial sewage containing As in Isfahan probably has contaminated water resources. A positive correlation was reported between As content in corn root and shoot parts with total content and absorbable content of $\mathrm{Zn}$ in soil (28).

\subsection{DIM and HIR of Elements}

The DIM was higher in children than adults, mainly through potato consumption (Appendix 1 in Supplementary File). The highest level of DIM was observed for Fe, P, and $\mathrm{N}$, and the lowest DIM was detected for Cd through consumption of potato. Therefore, compared to potato, HIR for As and P is of crucial importance and the entrance of these minerals to the food chain should be monitored.

The lowest amount of DIM via consuming cucumber was observed for $\mathrm{Pb}$, while the highest amount of DIM was measured for $\mathrm{P}$ and $\mathrm{N}$ (Appendix 2 in Supplementary File). Except for the RfD amount of As, P, and N, other minerals were lower than standard amounts. Therefore, cucumber consumption may cause negative health consequences by As for both children and adults. The results of the present study are not consistent with the findings of other studies conducted in Isfahan (29), probably due to the high pollution of fruits and vegetables in recent years.

The highest amounts of DIM by tomato consumption were observed for N, P, and Mn (Appendix 3 in Supplementary File). Except for the As and P, the amounts of HIR in other vegetables for adults and children were lower than one. The higher HIR for As and P can be due to the high content of those minerals in tomato. Also, tomatoes had a high-risk potential for As. The lowest and highest amounts of DIM for carrot consumption were observed for $\mathrm{Pb}$ and $\mathrm{P}$, respectively (Appendix 4 in Supplementary File). The upper amounts of DIM and HIR for P are due to the prevalent use of $\mathrm{P}$ fertilizers in the growth period of carrots. Although the concentrations of minerals were low in the soil, the mineral can be accumulated during plant growth.

The HIR through the consumption of lettuce for As and $P$ was higher than one (Appendix 5 in Supplementary File). The DIM for P was higher than the standard (based on RfD) for both adults and children. Similar to other vegetables, the highest DIM through spinach consumption was observed in $\mathrm{P}$, and $\mathrm{N}$. The highest HIR for children was obviously observed than adults. The amount of HIR for $\mathrm{N}$ in spinach was about one (Appendix 6 in Supplementary File).

\section{Discussion}

This study demonstrated high levels of $\mathrm{Cd}$ in vegetables and potato, mainly due to extensive use of chemical 


\begin{tabular}{|c|c|c|c|c|c|c|c|c|c|c|}
\hline \multirow{2}{*}{ Plants } & \multicolumn{10}{|c|}{ Elements } \\
\hline & Cd & $\mathrm{Cu}$ & $\mathrm{Fe}$ & $\mathbf{N i}$ & Mn & $\mathbf{P b}$ & Zn & As & $\mathbf{P}$ & $\mathbf{N}$ \\
\hline Cucumber & $0.91 b^{C}$ & $15.318^{B}$ & $2.832^{\mathrm{B}}$ & $1.290^{\mathrm{A}}$ & $56.502^{B}$ & $0.513^{\mathrm{D}}$ & $54.923^{\mathrm{A}}$ & $8.209^{\mathrm{D}}$ & $450.17^{\text {B }}$ & $286.33^{B}$ \\
\hline Tomato & $0.807^{C}$ & $14.598^{B}$ & $5.787^{B}$ & $1.595^{\mathrm{C}}$ & $75.097^{\mathrm{A}}$ & $0.075^{\mathrm{D}}$ & $35.945^{B}$ & $7.453^{\mathrm{D}}$ & $221.83^{\mathrm{D}}$ & ${ }_{162.17} \mathrm{C}$ \\
\hline Carrot & $0.972^{B}$ & $0.470^{\mathrm{E}}$ & $3.328^{B}$ & $0.402^{\mathrm{F}}$ & $57.54^{B}$ & $0.048^{\mathrm{D}}$ & $2.502^{\mathrm{E}}$ & $2.657^{\mathrm{E}}$ & $219.00^{\mathrm{D}}$ & $142.50^{\mathrm{C}}$ \\
\hline Lettuce & $0.282^{\mathrm{D}}$ & $8.067^{\mathrm{D}}$ & $1.318^{B}$ & $0.810^{\mathrm{E}}$ & $2.602^{\mathrm{D}}$ & $4.410^{\mathrm{C}}$ & $0.042 \mathrm{~F}$ & $10.35^{C}$ & $382.00^{\mathrm{C}}$ & $180.00^{C}$ \\
\hline Spinach & $1.180^{\mathrm{A}}$ & $27.723^{\mathrm{A}}$ & $6.180^{B}$ & $1.90^{\mathrm{B}}$ & $3.218^{\mathrm{D}}$ & $7.628^{B}$ & $5.534 \mathrm{C}$ & $16.02^{\mathrm{A}}$ & $387.00^{\mathrm{C}}$ & $344.00^{\mathrm{A}}$ \\
\hline SEM & 0.0214 & 0.1181 & 12.773 & 0.0411 & 0.5985 & 0.0984 & 0.1066 & 0.196 & 6.186 & 8.138 \\
\hline P value & $<0.0001$ & $<0.0001$ & $<0.0001$ & $<0.0001$ & $<0.0001$ & $<0.0001$ & $<0.0001$ & $<0.0001$ & $<0.0001$ & $<0.0001$ \\
\hline \multicolumn{11}{|l|}{ Safe limit (mg kg $\left.{ }^{-1}\right)$} \\
\hline FAO/WHO $(1984,2001 a)$ & 0.3 & 40 & 450 & 20 & - & 5 & 60 & $\cdot$ & $0.00-0.07$ & . \\
\hline SEPA China $(1995,2005)$ & 0.2 & 20 & . & 10 & . & 9 & 100 & 0.5 & . & . \\
\hline
\end{tabular}

${ }^{a}$ Means with the same capital letter in each column are not significantly different $(P<0.05)$.

(N, P, and potassium (K)) and animal fertilizers as well as pesticides in potato farms. The increase of $\mathrm{Cl}$ in the soluble phase of soil (due to using of $\mathrm{P}$ and $\mathrm{K}$ fertilizers) leads to increased levels of cadmium chloride in the soluble phase, which in turn results in enhanced bioavailability of Cd (30). Wangstrand et al. (31) reported that $\mathrm{N}$ fertilizers application had increased Cd concentration in soil, which in turn led to increased levels of Cd of wheat grains. Jalali and Khanlari (32) indicated that the mobile form of Cd in lime soils was higher during the cultivation of vegetables. Therefore, the long-term application of different fertilizers can increase the concentration of HM in plant biomass because many fertilizers contain HM or increase their mobility in the soil (33-35).

The concentration of Cd was higher than the safe limit $(36,37)$ for all plants, and the higher the concentration of $\mathrm{Cd}$ in the soil, the higher would be its concentration in plants. Besides, the amounts of lead measured in potato and air part of spinach were higher than the safe limits defined by the FAO/WHO (36), while these amounts were lower than the safe limits defined by the USEPA (37). However, the $\mathrm{Pb}$ for other vegetables was higher than the safe limits $(36,37)$.

In all plants, the measured level of copper was lower than the safe limits (29), except for spinach (37). Several studies reported lower concentrations of $\mathrm{Cu}(38,39)$. Nickel was lower than the safe limits in all plants $(36,37)$, and similar results are reported by Rashed (40). Chabukdhara et al., (41) found that the contents of $\mathrm{Cd}$ and $\mathrm{Pb}$ in vegetables were higher than the standard limits, but other $\mathrm{HMs}$ (Co, Cu, Cr, Fe, Mn, Ni, and Zn) were lower than the limits.

Zinc concentration was lower than the safe limit for all plants $(36,37)$. Similar findings are reported by Wu et al. and Gulz et al. (42) for corn, sunflower, and canola for As. Also, sewage application for plants has led to increased concentration of As in plants. Moreover, T Levels of $\mathrm{Cu}$ and $\mathrm{Zn}$ in fruits and vegetables did not also appear to expose serious health problems (43). Another study $(44,45)$ also showed that $\mathrm{P}$ fertilizers might cause a linear increase in $\mathrm{P}$ concentration of plants. Therefore, the higher amount of $P$ in plants in this study might be due to the extreme application of chemical P fertilizers. Increased level of As in soil caused to release $P$ from absorption sites and increase the availability of P by roots (46). Therefore, this interaction will determine the final concentration of $\mathrm{P}$ and As in plants.

Several factors contribute to nitrogen content, such as geographical condition, type and cultivar of plants, and cultivation condition, etc (46-48). Kenny and Walsh (49) reported that the concentration of $\mathrm{N}$ in carrot and cucumber was lower than the safe limits defined in European countries. Also, the $\mathrm{N}$ concentration in spinach of this study is in accordance with their study, but $\mathrm{N}$ in potato was higher than reported amounts by Kenny and Walsh (49). The $\mathrm{N}$ concentration in potato was reported $167 \mathrm{mg} \mathrm{kg}^{-1}$ (50), and the amount of $\mathrm{N}$ in the present study was lower than the safe limits of almost all European countries. The N concentration in lettuce and spinach changes widely depending on the season (51). The results of the present study showed that the lettuce and spinach were in reported ranges by safe limits.

The high HIR for Fe, $\mathrm{P}$, and $\mathrm{N}$ can be attributed to the high DI of potato and high concentration of these minerals in potato. Maynard and Hochmuth (52) reported that $\mathrm{N}$, P, and $\mathrm{K}$ fertilizers for potatoes applied in 100, 100, and 33 times more than tomato. There are risks of As for human health due to the consumption of contaminated potatoes, which is emphasized by the present study. Also, As in plants, especially in carrots, should be measured. The application of fertilizers and other amendments containing $\mathrm{HM}$ in cucumber farms will increase the HM accumulation 
of this vegetable. However, $\mathrm{Cd}$, As, and $\mathrm{Pb}$, among other minerals, cause extreme concerns because they can lead to serious diseases in adults and children (53).

\subsection{Conclusions}

Potato, tomato, cucumber, lettuce, and spinach are highly consumed vegetables in Iran, similar to many countries. Thus, the health risks of HM caused by consumption of these vegetables are a great concern in the study area, and more attention should be paid to the potential hazardous exposure to HM, especially for As, over the lifetime. For all vegetables, the concentrations of $\mathrm{N}$ and $\mathrm{P}$ were higher than the safe limits, which prohibited the entrance of these minerals to products. Possible measurements are necessary to effectively limit or prevent the health risk of vegetable consumption, such as careful peeling, selection of pollution-safe cultivars, and improvement of agricultural practices.

\section{Supplementary Material}

Supplementary material(s) is available here [To read supplementary materials, please refer to the journal website and open PDF/HTML].

\section{Footnotes}

Authors' Contribution: Study concept and design: Arasb. Dabbagh. Moghaddam., and Ahmad. Shahmoradi.; analysis and interpretation of data: Ahmad. Shahmoradi.; critical revision of the manuscript for important intellectual content: Arasb. Dabbagh. Moghaddam., and Ahmad. Shahmoradi.; statistical analysis: Ahmad. Shahmoradi.,

Conflict of Interests: The authors declare no conflict of interest.

Funding/Support: We didn't receive any funding for this research.

\section{References}

1. Harmanescu M, Alda LM, Bordean DM, Gogoasa I, Gergen I. Heavy metals health risk assessment for population via consumption of vegetables grown in old mining area; a case study: Banat County, Romania. Chem Cent J. 2011;5:64. doi: 10.1186/1752-153X-5-64. [PubMed: 22017878]. [PubMed Central: PMC3212802]

2. Ahmad JU, Goni MA. Heavy metal contamination in water, soil, and vegetables of the industrial areas in Dhaka, Bangladesh. Environ Monit Assess. 2010;166(1-4):347-57. doi: 10.1007/s10661-009-1006-6. [PubMed: 19521788].

3. Park RM, Bena JF, Stayner LT, Smith RJ, Gibb HJ, Lees PS. Hexavalent chromium and lung cancer in the chromate industry: a quantitative risk assessment. Risk Anal. 2004;24(5):1099-108. doi:10.1111/j.02724332.2004.00512.x. [PubMed: 15563281].
4. Al-Saleh I, Shinwari N, El-Doush I, Billedo G, Al-Amodi M, Khogali F. Comparison of mercury levels in various tissues of albino and pigmented mice treated with two different brands of mercury skin-lightening creams. Biometals. 2004;17(2):167-75. doi 10.1023/b:biom.0000018377.17857.88. [PubMed: 15088944].

5. Komarek M, Cadkova E, Chrastny V, Bordas F, Bollinger JC. Contamination of vineyard soils with fungicides: a review of environmental and toxicological aspects. Environ Int. 2010;36(1):138-51. doi: 10.1016/j.envint.2009.10.005. [PubMed: 19913914].

6. Abdulla M, Chmielnicka J. New aspects on the distribution and metabolism of essential trace elements after dietary exposure to toxic metals. Biol Trace Elem Res.1989;23:25-53. doi:10.1007/BF02917176. [PubMed: 2484425].

7. Bigdeli MSM. Investigation of Metals Accumulation in Some Vegetables Irrigated with Waste Water in Shahre Rey-Iran and Toxicological Implications. American-Eurasian Journal of Agricultural and Environmental Science. 2008;4:86-92.

8. Khan S, Cao Q, Zheng YM, Huang YZ, Zhu YG. Health risks of heavy metals in contaminated soils and food crops irrigated with wastewater in Beijing, China. Environ Pollut. 2008;152(3):686-92. doi: 10.1016/j.envpol.2007.06.056. [PubMed: 17720286].

9. D'Mello JPF. Food safety: Contaminants and toxins. Wallingford, Oxon, UK: CABI Publishing; 2003. 480 p.

10. Iyengar GV, Nair PP. Global outlook on nutrition and the environment: meeting the challenges of the next millennium. Sci Total Environ. 2000;249(1-3):331-46. doi: 10.1016/s0048-9697(99)00529-x. [PubMed: 10813462].

11. Türkdoğan M, Kilicel F, Kara K, Tuncer I, Uygan I. Heavy metals in soil, vegetables and fruits in the endemic upper gastrointestinal cancer region of Turkey. Environ Toxicol Pharmacol. 2003;13(3):175-9. doi: 10.1016/s1382-6689(02)00156-4.

12. Arora M, Kiran B, Rani S, Rani A, Kaur B, Mittal N. Heavy metal accumulation in vegetables irrigated with water from different sources. Food Chem. 2008;111(4):811-5. doi:10.1016/j.foodchem.2008.04.049.

13. Ghosh AK, Bhatt MA, Agrawal HP. Effect of long-term application of treated sewage water on heavy metal accumulation in vegetables grown in northern India. Environ Monit Assess. 2012;184(2):1025-36 doi: 10.1007/s10661-011-2018-6. [PubMed: 21494830].

14. Mapanda F, Mangwayana EN, Nyamangara J, Giller KE. The effect of long-term irrigation using wastewater on heavy metal contents of soils under vegetables in Harare, Zimbabwe. Agric Ecosyst Environ. 2005;107(2-3):151-65. doi: 10.1016/j.agee.2004.11.005

15. Cao H, Chen J, Zhang J, Zhang H, Qiao L, Men Y. Heavy metals in rice and garden vegetables and their potential health risks to inhabitants in the vicinity of an industrial zone in Jiangsu, China. J Environ Sci (China). 2010;22(11):1792-9. doi: 10.1016/s1001-0742(09)60321-1. [PubMed: 21235169].

16. Jones JJ. Laboratory guides for conducting soil tests and plant analysis. CRC Press; 2001.

17. Rattan RK, Datta SP, Chhonkar PK, Suribabu K, Singh AK. Long-term impact of irrigation with sewage effluents on heavy metal content in soils, crops and groundwater-a case study. Agric Ecosyst Environ. 2005;109(3-4):310-22. doi:10.1016/j.agee.2005.02.025.

18. Wang C, Chen Y, Liu J, Wang J, Li X, Zhang Y, et al. Health risks of thallium in contaminated arable soils and food crops irrigated with wastewater from a sulfuric acid plant in western Guangdong province, China. Ecotoxicol Environ Saf. 2013;90:76-81. doi 10.1016/j.ecoenv.2012.12.014. [PubMed: 23321363].

19. Ge KY. The status of nutrient and metal of Chinese in the 1990s. Beijing People's Hygiene Press. 1992:415-34.

20. Wang X, Sato T, Xing B, Tao S. Health risks of heavy metals to the general public in Tianjin, China via consumption of vegetables and fish. Sci Total Environ. 2005;350(1-3):28-37. doi: 10.1016/j.scitotenv.2004.09.044. [PubMed: 16227070].

21. USEPA. List of drinking water contaminants and MCLs. Washington, DC; 2002. Available from: https://www.epa.gov/ccl. 
22. Gupta N, Khan DK, Santra SC. An assessment of heavy metal contamination in vegetables grown in wastewater-irrigated areas of Titagarh, West Bengal, India. Bull Environ Contam Toxicol. 2008;80(2):115-8. doi: 10.1007/s00128-007-9327-z. [PubMed: 18165915].

23. Jamali MK, Kazi TG, Arain MB, Afridi HI, Jalbani N, Kandhro GA, et al. Heavy metal accumulation in different varieties of wheat (Triticum aestivum L.) grown in soil amended with domestic sewage sludge. J Hazard Mater. 2009;164(2-3):1386-91. doi: 10.1016/j.jhazmat.2008.09.056. [PubMed: 18977590].

24. Dogheim SM, Ashraf el MM, Alla SA, Khorshid MA, Fahmy SM. Pesticides and heavy metals levels in Egyptian leafy vegetables and some aromatic medicinal plants. Food Addit Contam. 2004;21(4):323-30. doi: 10.1080/02652030310001656361. [PubMed: 15204556].

25. Šrek P, Hejcman M, Kunzová E. Multivariate analysis of relationship between potato (Solanum tuberosum L.) yield, amount of applied elements, their concentrations in tubers and uptake in a longterm fertilizer experiment. Field Crops Res. 2010;118(2):183-93. doi: 10.1016/j.fcr.2010.05.009.

26. Koeppe DE. Lead: Understanding the minimal toxicity of lead in plants. In: Lepp NW, editor. Effect of Heavy Metal Pollution on Plants. 1 London: Springer, Dordrecht; 1981. p. 55-76.

27. Istvan Pais J, Benton Jones J. The handbook of trace elements. Florida: St Lucie press Boca Raton pub; 1997.

28. Mansouri T, Golchin A, Baba Akbari Sari M. The effect of arsenic on phosphorus, iron, zinc and manganese concentrations in soil and corn plant. Journal of Water and Soil (Agricultural Sciences And Technology). 2017;31(2):627-43.

29. Kafeshani O, Yahai M, Entezari MH, Hassanzadeh A, Mohebat L, Torabi A. Comparing the nitrate level in vegetables irrigated with zayandehrood river and well water. Health System Research. 2013;9(2).

30. Weggler K, McLaughlin MJ, Graham RD. Effect of chloride in soil solution on the plant availability of biosolid-borne cadmium. J Environ Qual. 2004;33(2):496-504. doi: 10.2134/jeq2004.4960. [PubMed: 15074800].

31. Wångstrand $\mathrm{H}$, Eriksson J, Öborn I. Cadmium concentration in winter wheat as affected by nitrogen fertilization. Eur J Agron. 2007;26(3):209-14. doi:10.1016/j.eja.2006.09.010.

32. Jalali M, Khanlari ZV. Environmental contamination of $\mathrm{Zn}, \mathrm{Cd}, \mathrm{Ni}, \mathrm{Cu}$, and $\mathrm{Pb}$ from industrial areas in Hamadan Province, western Iran. Environ Geol. 2007;55(7):1537-43. doi:10.1007/s00254-007-1103-1.

33. Keller A, Schulin R. Modelling heavy metal and phosphorus balances for farming systems. Nutr Cycling Agroecosyst. 2003;66(3):271-84. doi 10.1023/A:1024410126924

34. Jalali M, Moharami S. Effects of the addition of phosphorus on the redistribution of cadmium, copper, lead, nickel, and zinc among soil fractions in contaminated calcareous soil. Soil Sediment Contam. 2010;19(1):88-102. doi:10.1080/15320380903390521.

35. Jalali M, Moharami S. Redistribution of cadmium, copper, lead, nickel, and zinc among soil fractions in a contaminated calcareous soil after application of nitrogen fertilizers. J Soil Sci Plant Nutr.
2010;173(2):237-44. doi: 10.1002/jpln.200800143.

36. FAO. Compilation of legal limits for hazardous substance in fish and fishery products. FAO Fisheries Circular (FAO). 1983;464:5-100.

37. USEPA. Office of water regulations and standards. 2005. Available from: https://www.epa.gov/environmental-topics.

38. Terelak H, Stuczynski T, Piotrowska M. Heavy metals in agricultural soils in Poland. Pol J Soil Sci. 1997;30:35.

39. Ensminger AH, Ensminger ME, Konlande JE, Robson JR. The concise encyclopedia of foods \& nutrition. 1. CRC Press Inc;1995.184 p.

40. Rashed MN. Monitoring of contaminated toxic and heavy metals, from mine tailings through age accumulation, in soil and some wild plants at Southeast Egypt. J Hazard Mater. 2010;178(1-3):739-46. doi: 10.1016/j.jhazmat.2010.01.147. [PubMed: 20188467].

41. Chabukdhara M, Nema AK, Gupta SK. Metal contamination in market based vegetables in an industrial region, India. Bull Environ Contam Toxicol.2012;89(1):129-32. doi:10.1007/s00128-012-0613-z.[PubMed: 22476256].

42. Gulz PA, Gupta S, Schulin R. Arsenic accumulation of common plants from contaminated soils. Plant Soil. 2005;272(1-2):337-47. doi: 10.1007/s11104-004-5960-Z

43. Aydinalp $\mathrm{C}$, Marinova S. Concentration of $\mathrm{Cu}$ and $\mathrm{Zn}$ in some fruits and vegetables grown in Northwestern Turkey. Bulg J Agric Sci. 2012;18:749.

44. Tukaki JL, Mahler RL. Evaluation of nutrient solution phosphorus concentration on potato plantlet tuber production under greenhouse conditions1. J Plant Nutr. 1990;13(1):149-68. doi: $10.1080 / 01904169009364064$.

45. Rosen CJ, Bierman PM. Potato yield and tuber set as affected by phosphorus fertilization. Am J Potato Res. 2008;85(2):110-20. doi: 10.1007/s12230-008-9001-y.

46. Serio F, Elia A, Signore A, Santamaria P. Influence of nitrogen form on yield and nitrate content of subirrigated early potato. J Sci Food Agric. 2004;84(11):1428-32. doi: 10.1002/jsfa.1835.

47. Pavlou GC, Ehaliotis CD, Kavvadias VA. Effect of organic and inorganic fertilizers applied during successive crop seasons on growth and nitrate accumulation in lettuce. Sci Hortic. 2007;111(4):319-25. doi: 10.1016/j.scienta.2006.11.003.

48. Peksa A, Gołubowska G, Aniołowski K, Lisińska G, Rytel E. Changes of glycoalkaloids and nitrate contents in potatoes during chip processing. Food Chem. 2006;97(1):151-6. doi:10.1016/j.foodchem.2005.03.035.

49. Kenny TA, Walshe PE. Nitrate and nitrite contents of vegetables and fruits in Ireland. Ireland Journal of Agriculture Research. 1975;14:349-55.

50. MAFF. Nitrate in Vegetables Food Surveillance Information Sheet.UK: Ministry of Agriculture FaF; 1998.158 p.

51. WHO. Nitrite-intake assessment. Safety evaluation of certain food. 2003;50:1053-71.

52. Maynard DN, Hochmuth GJ. Knott's handbook for vegetable growers. New York: John Wiley and Sons; 1997.

53. Bailey RA, Clark HM, Ferris JP, Krause S, Strong RL. Chemistry of the Environment. Elsevier; 2002 